Creative Commons User License: CC BY-NC-ND

Abstracted by: EBSCOhost, Electronic Journals Service (EJS),

Google Scholar, Journal Seek, Scientific Commons,

Food and Agricultural Organization (FAO), CABI and Scopus

http://eoi.citefactor.org/10.11226/v23i1
Journal of Agricultural Extension

Vol. 23 (1) January, 2019

ISSN(e): 24086851; ISSN(Print); 1119944X

http://journal.aesonnigeria.org

http://www.ajol.info/index.php/jae

Email: editorinchief@aesonnigeria.org

\title{
Farmers' Perceived Effectiveness of the Growth Enhancement Support Scheme in Kogi State, Nigeria
}

https://dx.doi.org/10.4314/jae.v23i1.10

Agwu, Ekwe. A.

Department of Agricultural Extension, University of Nigeria, Nsukka.

agwuekwe@hotmail.com ; ekwe.agwu@unn.edu.ng

$+2348034024251$

Ndakotsu, John. E.

Ministry of Agriculture and Rural Development, Lokoja, Kogi State, Nigeria.

ndakotsujohn@yahoo.com

Ifeonu, Chidimma. $\mathbf{F}$.

Department of Agricultural Extension, University of Nigeria, Nsukka.

phrancesleaticia@gmail.com

$+2347037085498$

\section{Abstract}

The study determined farmers' perceived effectiveness of the Growth Enhancement Support (GES) Scheme in Kogi State, Nigeria. A total of 120 scheme participants were purposively selected and interviewed from 12 communities across six local government areas. The results revealed that the majority of the respondents (85.8\%) had access to agriculture-related information. The major crops grown in the area included maize (84.2 \%), cassava (80.8\%)and rice (48.8\%). Respondents had a very high knowledge (80\%) of the schemes' activities and the major source of information on the scheme activities was extension agents (78.3\%). Again, respondents percieved a few of the scheme's operational processes, namely, the use of phone in information dissemination $(\bar{x}=2.21)$, registration process of the scheme $(\bar{x}=2.18)$, channels used for the sheme implementation $(\bar{x}=2.17)$, farmers' sensitization process $(\bar{x}=2.04)$ and types of personnel used $\bar{x}=2.02)$ as having high level of effectivessness. They were equally satisfied with some implementation processes of the scheme, namely, quality of seeds provided $(\bar{x}=2.15)$, level of subsidy provided by the scheme $(\bar{x}=2.05)$ and fertilizer distribution methods $(\bar{x}=2.00)$, among others. However, the major constraints to effective implementation of the scheme included untimely input provision $(\bar{x}=2.20)$, inability to still pay for the subsidized inputs by the farmers $\bar{x}=2.31)$ and inability to purchase mobile phones $(\bar{x}=2.08)$. The study points to the need for early inputs provisions to farmers as farming operations are time bound. There is also the need to focus attention on encouraging more women to participate in the scheme in order to achieve its main objective of increased productivity and household food security.

Keywords: food security, input supply, knowledge index, mobile phone 
Creative Commons User License: CC BY-NC-ND

Abstracted by: EBSCOhost, Electronic Journals Service (EJS),

Google Scholar, Journal Seek, Scientific Commons,

Food and Agricultural Organization (FAO), CABI and Scopus

http://eoi.citefactor.org/10.11226/v23i1
Journal of Agricultural Extension

Vol. 23 (1) January, 2019

ISSN(e): 24086851; ISSN(Print); 1119944X

http://journal.aesonnigeria.org

http://www.ajol.info/index.php/iae

Email: editorinchief@aesonnigeria.org

\section{Introduction}

The Nigerian economy was strongly dependent on agriculture for many years before the discovery of oil in 1956. Agricultural enterprises such as cocoa, groundnut, oil palm and cotton production accounted for a large chunk of foreign exchange earnings in Nigeria. The south-western zone of the country was renowned mainly for its cocoa production and the South East together with South-South zones were renowned for oil palm production, while the Northern part of the country was renowned for its groundnut and cotton production. Nigeria was also one of the largest exporters of oil palm and cocoa until the discovery of crude oil, which resulted in the partial neglect of the agricultural sector. Even with the decline in output, the sector has continued to contribute about $22.86 \%$ to Nigeria's GDP (National Bureau of Statistics (NBS), 2018).

Agriculture is predominantly practised in the rural areas of Nigeria. Most farmers in these areas could not embark on mechanized agriculture because of the high rate of poverty that is prevalent in rural areas coupled with the land tenure system still practised in most places; hence, the need for farmers in rural areas to have access to farm inputs such as fertilizers, seeds among other critical factors of production. In view of this, in July 2012 the Federal Government of Nigeria introduced the Growth Enhancement Support (GES) scheme and this was designed to deliver government subsidised farm inputs directly to farmers via GSM phones. The GES scheme, according to Adesina (2012), is powered by e-Wallet, an electronic distribution channel, which provides an efficient and transparent system for the purchase and distribution of agricultural inputs based on a voucher system. The scheme guarantees registered farmers e-Wallet vouchers with which they can collect fertilisers, seeds and other agricultural inputs from agro-dealers at half the cost, the other half being borne by the federal and state governments in equal proportions. As part of the GES scheme, the Federal Ministry of Agriculture and Rural Development announced that the ministry would equip millions of farmers in the rural areas with mobile phones (Adesina, 2013). Adesina (2013), further stressed that the project would link farmers directly to government and vice-versa so that Government would be able to monitor the progress of farmers as well as disseminate valuable information to them.

The scheme, according to the Federal Ministry of Agriculture and Rural Development (FMARD) (2012), represents a policy and pragmatic shift within the existing fertilizer market stabilization programme and puts the resource-constrained farmer at the centre through the provision of series of incentives to encourage the critical actors in the fertilizer value chain to work together to improve productivity, household food security and income of the farmer. The goals of GES include to:

(a) target 5 million farmers in each year for four (4) years that will receive GES in their mobile phones directly, totalling 20 million at the end of the 4 years;

(b) provide support directly to farmers to enable them procure agricultural inputs at affordable prices and at the right time and place;

(c) increase productivity of farmers across the length and breadth of the country through increased use of fertilizer i.e. $50 \mathrm{~kg} / \mathrm{ha}$ from $13 \mathrm{~kg} / \mathrm{ha}$; and

(d) change the role of Government from direct procurement and distribution of fertilizer to a facilitator of procurement, regulator of fertilizer quality and catalyst of active private sector participation in the fertilizer value chain. 
Creative Commons User License: CC BY-NC-ND

Abstracted by: EBSCOhost, Electronic Journals Service (EJS),

Google Scholar, Journal Seek, Scientific Commons,

Food and Agricultural Organization (FAO), CABI and Scopus

http://eoi.citefactor.org/10.11226/v23i1
Journal of Agricultural Extension

Vol. 23 (1) January, 2019

ISSN(e): 24086851; ISSN(Print); 1119944X

http://journal.aesonnigeria.org

http://www.ajol.info/index.php/iae

Email: editorinchief@aesonnigeria.org

Thirty-five (35) states of the country excluding Zamfara keyed into the programme for implementation with various farm inputs being redeemed to registered farmers at designated redemption centres (FMARD, 2013).

The introduction of Growth Enhancement Support (GES) scheme was received with scepticism among Nigerians considering all that led to the failure of past agricultural development policies. From the stated goals of the GES scheme, it is quite clear that the idea behind the introduction of the scheme are lofty and commendable but the question is whether the process of implementation was effective enough to achieve the set goals and objectives? It is then of importance to explain how the scheme has been implemented in Kogi State and the general perception of farmers towards the implementation process of the scheme. It is against this background that this study sought to answer these pertinent questions: What are the farmers' perceptions of the GES schemes? What are the sources of information on the schemes' activities? What is the level of satisfaction on the schemes' implementation process? What are the perceived constraints to effective implementation of the scheme? What are the perceived strategies for effective implementation of the scheme in Kogi State of Nigeria?

\section{Objectives of the study}

The overall purpose of the study was to determine the farmers' perceived effectiveness of the Growth Enhancement Support (GES) scheme in Kogi State. Specifically, the study sought to:

- ascertain farmers' perceived effectiveness of the scheme;

- determine farmers' knowledge of the activities of GES scheme in Kogi State;

- identify farmers' major sources of information on the GES scheme activities;

- determine farmers' level of satisfaction in the implementation of the scheme;

- determine perceived constraints to effective implementation of the GES scheme; and

- determine the strategies for effective implementation of the programme.

\section{Hypothesis}

The socio-economic and institutional characteristics of rural farmers have no significant influence on their knowledge level of the GES scheme.

\section{Methodology}

\section{Area of study}

The study was carried out in Kogi State, Nigeria, located between latitude $7^{\circ} .45 \mathrm{~N}$ and $8.100^{\circ} \mathrm{N}$ and Longitude $6^{\circ} 45 \mathrm{E}$ and $6.800^{\circ} \mathrm{E}$ (www.kogistatenigeria/aboutus.org). It is characterized with geological features depicting young sedimentary rocks and alluvial soil along the riverbeds which promotes agricultural activities. The State produces crops like yam, cassava, soya bean, cocoyam, maize, millet, rice, guinea corn, oil palm, cowpea and others. Some cash crops like cocoa, coffee and cashew are also grown in the State (Aderolu, et. al., 2014).

\section{Population and sampling procedure}

Multistage sampling procedure was used in selecting respondents for this study. In stage one, 6 LGAs were purposively selected out of the 21 LGAs based on their level of 
Creative Commons User License: CC BY-NC-ND

Abstracted by: EBSCOhost, Electronic Journals Service (EJS),

Google Scholar, Journal Seek, Scientific Commons,

Food and Agricultural Organization (FAO), CABI and Scopus
Journal of Agricultural Extension

Vol. 23 (1) January, 2019

ISSN(e): 24086851; ISSN(Print); 1119944X

http://journal.aesonnigeria.org

http://www.ajol.info/index.php/iae

Email: editorinchief@aesonnigeria.org

http://eoi.citefactor.org/10.11226/v23i1

participation in the schemes' activities. The LGAs were Bassa, Lokoja, Ajaokuta, Adavi, Kogi and Dekina. The second stage was the random selection of two communities of GES scheme participants from each of the 6 LGAs, making 12 communities. In the third stage, 10 participants were randomly selected from each of the communities with the assistance of the help line officers. This gave a total number of 120 farmers used for the study.

\section{Measurement of variables}

Socio-economic and institutional characteristics: These include sex, age, religion, and marital status, educational level, farming experience, farm size, household size and membership of a social/religious organization. These were measured at nominal and ordinal levels.

Farmers' perceived effectiveness of the scheme: some of the parameters measured include: the registration process of the scheme, timely inputs redemption, timely access to information on the schemes' activities etc. A three - point Likert type scale with response options of very effective $=3$, effective $=2$, not effective $=1$, was used. The cut-off mean was 2. Variables with mean scores of 2 and above were perceived as having high level of effectiveness while those variables with mean score less than two were perceived as having low level of effectiveness.

Farmers' knowledge of the activities of GES scheme in Kogi State: respondents reacted to fifteen open and close (structured) questions by ticking either yes/no and provided answers to the open ended questions in order to ascertain their knowledge level. Each correct answer was scored one (1) point, giving the highest score of 15 points, and the lowest was 0 . The respondents were thereafter categorized into three groups based on their knowledge level of the scheme. These are: high knowledge (from score 11-15), moderate knowledge (from score 6-10) and low knowledge (from score 1-5).

Major sources of information on the GES scheme activities: list of all possible sources of information was provided and the respondents were required to the tick the appropriate option. Their choices were later ranked according to the frequency of their response to a particular livelihood activity. Some of the options include: radio, television, friends and neighbors, extension agents, ministry of agriculture workers, Fadama facilitators, and fellow farmers.

Farmers' level of satisfaction in the implementation of the scheme; to determine their level of satisfaction, a three - point Likert- type scale with response options of very satisfactory= 3 , satisfactory $=2$, not satisfactory $=1$ was used. The cut-off mean was 2 . Variables with mean scores above 2 were regarded as satisfactory implementation process, while those with less than 2 were regarded as unsatisfactory process of implementation.

Perceived constraints to effective implementation of the GES scheme; respondents reacted to fifteen constraints items measured on the scale of as very serious constraint $=3$, serious constraint $=2$ and not serious constraint $=1$. The mean scores were obtained and ranked to determine the constraints to effective implantation of the GES scheme. Data were also subjected to exploratory factor analysis procedure using the principal factor model with varimax rotation in grouping the constraint variables into major constraint factors. However, only variables with loading of 0.40 and above (10\% overlapping variance) were used in naming the factors. 
Creative Commons User License: CC BY-NC-ND

Abstracted by: EBSCOhost, Electronic Journals Service (EJS),

Google Scholar, Journal Seek, Scientific Commons,

Food and Agricultural Organization (FAO), CABI and Scopus

http://eoi.citefactor.org/10.11226/v23i1
Journal of Agricultural Extension

Vol. 23 (1) January, 2019

ISSN(e): 24086851; ISSN(Print); 1119944X

http://journal.aesonnigeria.org

http://www.ajol.info/index.php/jae

Email: editorinchief@aesonnigeria.org

Strategies for effective implementation of the programme. The respondents suggested the possible strategies that will enhance effective implementation of the programme in the state.

The hypothesis was tested using multiple regression analysis and the regression model is specified as follows:

$Y=\alpha+\beta_{1} X_{1}+\beta_{2} X_{2}+\beta_{3} X_{3} \ldots+\beta_{14} X_{14}+U$

Where: $Y=$ Knowledge scores on Growth Enhancement Support scheme by each respondent.

$\alpha=$ Constant term

$\beta_{1}-\beta_{14}=$ regression coefficients.

$X_{1}=\operatorname{sex}($ male $=1$, female $=2), X_{2}=$ age (years), $X_{3}=$ marital status (married=1, not married $=2), X_{4}=$ educational level (number of years spent in formal education), $X_{5}=$ religion (Christianity $=1$, Muslim $=2$ ), $X_{6}=$ farming experience (years), $X_{7}=$ access to information related to GES implementation.(yes $=1$, no $=2$ ), $X_{8}=$ ownership of mobile phones. (yes=1, no=2), $X_{9}=$ farm size (in hectares), $X_{10}=$ farm Income $(\mathbb{N}), X_{11}=$ household size(actual number of people living in the house), $X_{12}=$ membership of social/religious organization belong to.(yes=1, no= 2), $\mathrm{X} 13=$ type of crops grown (specific crops grown by respondents), $\mathrm{X} 14$ = years of participation (the actual years of participation in the scheme).

Data for this study were collected using structured questionnaire and analysed using percentage, frequency, mean scores, factor analysis and regression analysis.

\section{Results and Discussion}

\section{Socio-Economic/Institutional Characteristics of Respondents}

Table 1 shows that the majority $(78.3 \%)$ of the scheme participants were male. This could be attributed to the drudgery associated with farm work. The mean age of the respondents was 42.4 years, implying that most of the farmers in the area are strong and still very active to carry out agricultural activities. The majority $(88.4 \%)$ of the respondents were married and this will have a great influence in farm labour availability. A greater proportion $(40 \%)$ of the respondents had HND/B.Sc. certificates as their highest qualification. This implies that the respondents were generally literate and such can enhance utilization of information on agricultural food production. Table 1 further shows that the mean house hold size was 5 persons; this implies that respondents have access to family labour which could positively affect agricultural production. On the negative side, Bola, Aliou and Omonona, (2012) reported that a larger household size could as well worsen the poverty situation particularly if such composition is more of dependants.

The majority (54.2\%) of the respondents were of the Christian faith while the remaining $45.8 \%$ of the respondents were Muslims. The mean farming experience was 18.6 years; this shows that quite a number of the respondents have been into agricultural food production for a long time. The mean farm size was 2.5 hectares. This implies that the respondents are small scale farmers and are therefore qualified to participate and benefit from the GES scheme since the scheme was meant for the small holder farmers. The mean farm income was $\$ 47,605.00$ monthly and by implication many of them are most likely to participate in the schemes' operations. This is particularly so as farmers were required to pay for the subsidized inputs provided. 
Creative Commons User License: CC BY-NC-ND

Abstracted by: EBSCOhost, Electronic Journals Service (EJS),

Google Scholar, Journal Seek, Scientific Commons,

Food and Agricultural Organization (FAO), CABI and Scopus

http://eoi.citefactor.org/10.11226/v23i1
Journal of Agricultural Extension

Vol. 23 (1) January, 2019

ISSN(e): 24086851; ISSN(Print); 1119944X

http://journal.aesonnigeria.org

http://www.ajol.info/index.php/jae

Email: editorinchief@aesonnigeria.org

Table 1 also reveals that the majority (99.2\%) of the respondents owned mobile phones, while a few $(0.8 \%)$ had no mobile phones. Ownership of mobile phone by the respondents is important because this will enable them participate and benefit from the scheme. The majority $(85 \%)$ of the respondents in the study areas had access to agricultural related information. The majority (85.8\%) of the respondents belonged to one social/religion organization or the other, while the remaining $16.8 \%$ did not belong to any. These organizations according to Ojiagu, Onugu \& Uchenna (2015), could serve as channels for contact with larger members of other practitioners, as these offer opportunities for participatory interaction with extension organizations. 
Creative Commons User License: CC BY-NC-ND

Abstracted by: EBSCOhost, Electronic Journals Service (EJS),

Google Scholar, Journal Seek, Scientific Commons,

Food and Agricultural Organization (FAO), $\mathrm{CABI}$ and Scopus

http://eoi.citefactor.org/10.11226/v23i1
Journal of Agricultural Extension

Vol. 23 (1) January, 2019

ISSN(e): 24086851; ISSN(Print); 1119944X

http://journal.aesonnigeria.org

http://www.ajol.info/index.php/jae

Email: editorinchief@aesonnigeria.org

Table 1: Socio-economic and institutional characteristics

\begin{tabular}{|c|c|c|}
\hline \multirow{2}{*}{\multicolumn{3}{|c|}{$\begin{array}{l}\text { Socio-economic/ Institutional characteristics } \\
\text { Sex }\end{array}$}} \\
\hline & & \\
\hline Male & 78.3 & \\
\hline Female & 21.7 & \\
\hline \multicolumn{3}{|l|}{ Age (years) } \\
\hline 30 and above & 11.7 & \\
\hline $31-40$ & 33.3 & \\
\hline $41-50$ & 31.7 & \\
\hline $51-60$ & 23.3 & 42.4 years \\
\hline \multicolumn{3}{|l|}{ Marital status } \\
\hline Married & 88.4 & \\
\hline Single & 9.2 & \\
\hline Widowed & 1.6 & \\
\hline Divorced & 0.8 & \\
\hline \multicolumn{3}{|l|}{ Educational level } \\
\hline No formal education & 9.2 & \\
\hline Primary school leaver & 7.5 & \\
\hline Secondary school attempted & 5.8 & \\
\hline Secondary school completed & 11.8 & \\
\hline ND/NCE & 16.6 & \\
\hline HND/B.sc & 40.0 & \\
\hline Higher degree & 9.2 & \\
\hline Mean of years spent in acquiring formal education & & 13.5 years \\
\hline \multicolumn{3}{|l|}{ Household size (number) } \\
\hline $1-5$ & 43.3 & \\
\hline $6-10$ & 50.0 & \\
\hline $11-15$ & 7.7 & 5 persons \\
\hline \multicolumn{3}{|l|}{ Religion } \\
\hline Christian & 54.2 & \\
\hline Muslim & 45.8 & \\
\hline \multicolumn{3}{|l|}{ Farming experience(years) } \\
\hline $1-10$ & 26.7 & \\
\hline $11-20$ & 35.0 & \\
\hline $21-30$ & 25.0 & \\
\hline $31-40$ & 13.3 & 18.6 years \\
\hline \multicolumn{3}{|l|}{ Farm size (hectare) } \\
\hline $1 / 2-2 h a$ & 50.0 & \\
\hline 3ha-4ha & 24.2 & \\
\hline 5ha-6ha & 25.8 & $2.5 \mathrm{ha}$ \\
\hline \multicolumn{3}{|l|}{ Farm income } \\
\hline None & 18.3 & \\
\hline N100 - N50,000 & 45.8 & \\
\hline N50001 - N100,000 & 16.7 & N47.605 \\
\hline N10001 - N200,000 & 14.2 & \\
\hline Above - N200001 & 5 & \\
\hline \multicolumn{3}{|l|}{ Ownership of mobile phones } \\
\hline Yes & 99.2 & \\
\hline \multicolumn{3}{|l|}{ Access to agricultural information } \\
\hline Yes & 85.8 & \\
\hline \multicolumn{3}{|l|}{ Membership of social/religion organization } \\
\hline Yes & 83.2 & \\
\hline
\end{tabular}


Creative Commons User License: CC BY-NC-ND

Abstracted by: EBSCOhost, Electronic Journals Service (EJS),

Google Scholar, Journal Seek, Scientific Commons,

Food and Agricultural Organization (FAO), CABI and Scopus

http://eoi.citefactor.org/10.11226/v23i1
Journal of Agricultural Extension

Vol. 23 (1) January, 2019

ISSN(e): 24086851; ISSN(Print); 1119944X

http://journal.aesonnigeria.org

http://www.ajol.info/index.php/iae

Email: editorinchief@aesonnigeria.org

\section{Perceived effectiveness of GES scheme}

Entries in Table 2 indicate the perceived effectiveness of the scheme's implementation. Variables with perceived high level of effectiveness include: the use of mobile phones in information dissemination ( $\bar{x}=2.21)$, the process of registration $(\bar{x}=2.18)$, the channel used for the implementation $(\bar{x}=2.17)$, the sensitization process in preparation for the schemes' participation $(\bar{x}=2.04)$ and the type of personnel used for the schemes' activities $(\bar{x}=2.02)$. Such perception of the schemes' activities by respondents could be as a result of their participation in the activities coupled with the knowledge gathered from such participation. According to Aphunu and Nwabueze (2012), the higher the knowledge of a given programme, the more participants perceive its impacts.

On the other hand, the remaining variables had perceived low level of effectiveness. These areas of perceived low level of effectiveness could hinder the general success of the scheme if not improved upon. Therefore, improving on these implementation processes is important as peoples' participation in any developmental programmes are usually influenced by their perception.

Table 2: Farmers' perceived effectiveness of GES

\begin{tabular}{lll}
\hline Perception variables & & \\
& Mean (M) & Std. Deviation \\
\hline Use of phone in information disseminating & $2.21^{*}$ & 0.672 \\
Registration process of the scheme & $2.18^{\star}$ & 0.534 \\
Channels use for the scheme implementation & $2.17^{*}$ & 0.587 \\
Farmers' sensitization process & $2.04^{*}$ & 0.556 \\
Types of personnel used & $2.02^{*}$ & 0.547 \\
Fertilizer distribution effectiveness & 1.99 & 0.527 \\
The seed distribution effectiveness & 1.97 & 0.542 \\
Method of seed supply & 1.93 & 0.576 \\
Use of e-wallet in input redemption & 1.93 & 0.576 \\
Timely inputs redemption & 1.53 & 0.607 \\
Inputs redemption and it regularity & 1.44 & 0.576 \\
Overall mean & $\mathbf{1 . 9 5}$ & $\mathbf{0 . 5 7 3}$ \\
\hline
\end{tabular}

Perceived high level of effectiveness*

\section{Farmers' knowledge of Growth Enhancement Support Scheme}

Table 3 reveals that $95 \%$ of the respondents knew that GES scheme was generally designed by the government to provide incentive to farmers in order to ensure food security. About $88 \%$ of the respondents were aware that you can only benefit from the scheme when you are fully registered. However, only $29.4 \%$ of the total respondents were aware of the period such registration is expected to last. For this reason, creation of more awareness in that direction will be required.

Also, $80.9 \%$ of the participants had knowledge on the use of e-wallet vouchers as an electronic device for input redemption. Farmers that knew that having a good telephone network is important for the schemes' operations and type of inputs supported by the scheme accounted for $97.5 \%$, respectively. Having such knowledge is vital as this will enable the scheme's participants know what to demand for during input redemption. The 
Creative Commons User License: CC BY-NC-ND

Abstracted by: EBSCOhost, Electronic Journals Service (EJS),

Google Scholar, Journal Seek, Scientific Commons,

Food and Agricultural Organization (FAO), CABI and Scopus

http://eoi.citefactor.org/10.11226/v23i1
Journal of Agricultural Extension

Vol. 23 (1) January, 2019

ISSN(e): 24086851; ISSN(Print); 1119944X

http://journal.aesonnigeria.org

http://www.ajol.info/index.php/iae

Email: editorinchief@aesonnigeria.org

study further reveals that $77.5 \%$ of the respondents are knowledgeable as to whether both cash and food crops are supported by the scheme. Knowledge as to whether the scheme discriminates against any gender had $96.4 \%$.

Farmers seem not to be knowledgeable on the specific benefit that can be derived from the scheme as this accounted for $30.9 \%$ of the total respondents. Being knowledgeable of the benefits that can accrue from participating in the scheme is very important as this will enhance peoples' level of participation in the schemes' activities, thereby achieving the expected positive results.

Table 3: Percentage distribution of respondents by their knowledge scores Knowledge items

The general purpose of the scheme

Percentage

The need to register for participation

95.0

The expected period the registration is to last

88.4

As an initiation of the federal government

29.4

95.9

The function of e-wallet voucher to the scheme

80.9

The specific crops supported by the scheme

42.5

On how subsidies on inputs are borne by both federal and state 73.4 governments

Type of people encouraged for participation

81.7

The importance of having a good telephone network

97.5

As to whether both seeds and fertilizers are supported together $\quad 97.5$

The importance of having mobile phone for the Schemes' participation $\quad 97.5$

Whether the scheme discriminate against gender

96.4

As to whether cash and food crops are supported

77.5

The type of fertilizer supported by the scheme

84.2

The specific benefit of the scheme to the participant

30.9

Table 4 further revealed that the majority ( $80 \%)$ of the respondents had high knowledge on the schemes' activities. Those with moderate knowledge accounted for $17.5 \%$, while the remaining $2.5 \%$ of the respondents had low knowledge. Having high knowledge on the schemes' activities might be as a result of the adequate sensitization being carried out prior to the commencement of the scheme. It is then expected that such knowledge will influence the farmers' decision making as to whether to participate in the schemes' activities or not.

Table 4: Farmers' knowledge level on GES scheme

\begin{tabular}{lll}
\hline Knowledge level & Frequency & $(\mathbf{n}=120)$ \\
\hline High knowledge & 80 & \\
Moderate knowledge & 17.5 \\
Low Knowledge & 2.5 \\
\hline
\end{tabular}

\section{Sources of Information on Growth Enhancement Support (GES) scheme}

Results in Table 5 reveal that the majority (78.3\%) of the respondents sourced information on the scheme's activities from extension agents, followed by the state ministry of 
Creative Commons User License: CC BY-NC-ND

Abstracted by: EBSCOhost, Electronic Journals Service (EJS),

Google Scholar, Journal Seek, Scientific Commons,

Food and Agricultural Organization (FAO), CABI and Scopus

http://eoi.citefactor.org/10.11226/v23i1
Journal of Agricultural Extension

Vol. 23 (1) January, 2019

ISSN(e): 24086851; ISSN(Print); 1119944X

http://journal.aesonnigeria.org

http://www.ajol.info/index.php/iae

Email: editorinchief@aesonnigeria.org

agriculture $(75 \%)$. Other sources include: mobile phone $(73.3 \%)$, radio $(71.6 \%)$ and friends and neighbours $(70 \%)$.

On the other hand, magazines (15.5\%), billboards (21.6\%), internets (30\%), and town crier $(35.8 \%)$ were low sources of information to participants. The GES scheme was originally designed to transmit valuable information on its activities to the participants via mobile phones, which was considered most effective means of reaching out to the participants. According to Adesina (2012) the scheme is expected to make use of mobile phones to transmit information on its' activities in order to link farmers directly to government and vice-versa as such will enable government to monitor the progress of farmers, as well as, disseminate valuable information to them. Contrary to this expectation, the study revealed extension agents as the information source that ranked highest on the GES scheme.

Table 5: Percentage distribution of information sources on GES

\begin{tabular}{|c|c|c|}
\hline Information sources & Percentage $^{\star}$ & Ranking \\
\hline Extension Agents & 78.3 & $1^{\text {st }}$ \\
\hline Min. of Agriculture & 75.0 & $2^{\text {nd }}$ \\
\hline Mobile phones & 73.3 & $3^{\text {rd }}$ \\
\hline Radio & 71.6 & $4^{\text {th }}$ \\
\hline Friends and neighbours & 70.0 & $5^{\text {th }}$ \\
\hline Fadama facilitators & 67.5 & $6^{\text {th }}$ \\
\hline Television & 64.0 & $7^{\text {th }}$ \\
\hline Family members & 56.6 & $8^{\text {th }}$ \\
\hline Community leaders & 50.8 & $9^{\text {th }}$ \\
\hline Community association & 50.0 & $10^{\text {th }}$ \\
\hline Newspapers & 40.8 & $11^{\text {th }}$ \\
\hline Posters & 39.1 & $12^{\text {th }}$ \\
\hline Worship centres & 38.3 & $13^{\text {th }}$ \\
\hline Town crier & 35.8 & $14^{\text {th }}$ \\
\hline Inputs sellers & 30.1 & $15^{\text {th }}$ \\
\hline Internets & 30.0 & $16^{\text {th }}$ \\
\hline Billboards & 21.6 & $17^{\text {th }}$ \\
\hline Magazines & 15.5 & $18^{\text {th }}$ \\
\hline
\end{tabular}

${ }^{\star}$ Multiple responses

Farmers Level of Satisfaction with the Scheme's Activities Implementation Process

Entries in Table 6 indicate the respondents' level of satisfaction with the scheme's implementation process. These include: the quality of seeds provided $(\bar{x}=2.15)$, the level of subsidy provided ( $\bar{x}=2.07)$ and the method of information dissemination on the schemes' activities $(\bar{x}=2.02)$.Others include: the registration process of the scheme $(\bar{x}=2.0)$ and fertilizer distribution method ( $\bar{x}=2.00)$. Participants' satisfaction in these implementation processes of the scheme especially in the area of fertilizer distribution process is a good development since it was one of the major problems faced by Nigerian farmers that the Scheme was established to address. 
Creative Commons User License: CC BY-NC-ND

Abstracted by: EBSCOhost, Electronic Journals Service (EJS),

Google Scholar, Journal Seek, Scientific Commons,

Food and Agricultural Organization (FAO), CABI and Scopus

http://eoi.citefactor.org/10.11226/v23i1
Journal of Agricultural Extension

Vol. 23 (1) January, 2019

ISSN(e): 24086851; ISSN(Print); 1119944X

http://journal.aesonnigeria.org

http://www.ajol.info/index.php/iae

Email: editorinchief@aesonnigeria.org

However, the following aspects of the scheme were not perceived as satisfactory by the respondents: the quantity of seed provided ( $\bar{x}=1.92)$, the general operation of the scheme $(\bar{x}=1.92)$, ability to reconcile the electronic channels with farmers registered list $(\bar{x}=1.82)$, the quality of fertilizer provided ( $\bar{x}=1.72)$, the timing of inputs provision $(\bar{x}=1.37)$, among others. These unsatisfactory areas are also critical, especially the issue of timely input provision, as this can hinder the success of the scheme. Bola, Aliou \& Omonona (2012) remarked that untimely access to agro-inputs can negatively affect the adoption of technologies as well as farmers' participation in the GES scheme.

Table 6: Farmers level of satisfaction with the implementation of the scheme Variables

The quality of seed provided

The level of subsidy provided by the scheme

Registration process of the scheme

Method of information dissemination on the schemes' activities

The fertilizer distribution method

The channels used in execution of the schemes' activities

The farmers' sensitization process on the schemes' activities.

Type and number of personnel used

Seed distributed method

The general operations of the scheme

The ability to reconcile the electronic distribution channels with the farmers registration list

The quantity of seeds provided

The quality of fertilizer provided

Timely input redemption

Mean (M)

Std.

$2.15^{*}$

Deviation

Timelingut redemption

\section{Perceived constraints to effective implementation of GES scheme Activities}

Results in Table 7 show various constraints to effective implementation of Growth Enhancement Support (GES) scheme as indicated by respondents. The major constraints identified were: farmers not being able to read text messages on their phones $(\bar{x}=2.36)$, farmers not being able to still pay for subsidized inputs $(\bar{x}=2.31)$, untimely input provision $(\bar{x}=2.20)$, and lack of good road to get farmers in rural areas registered $(\bar{x}=2.18)$.

Listed among the major constraints is the fact that some farmers were not able to read text messages on their phones. This has grave implication on the success of the Scheme as farmers are expected to be informed through the text messages of the availability of necessary inputs. Also, timely inputs provision as at when due is very important if the set goals of the Scheme must be achieved, as most of the agricultural operations are time bound. Similarly, Ogbonna (2014), identified delay in input supply as a major constraint to effective farming and extension performance in Green River Project of Imo and Rivers States and such was reported to be capable of posing a hindrance to the effective performance of the scheme. 
Creative Commons User License: CC BY-NC-ND

Abstracted by: EBSCOhost, Electronic Journals Service (EJS),

Google Scholar, Journal Seek, Scientific Commons,

Food and Agricultural Organization (FAO), CABI and Scopus

http://eoi.citefactor.org/10.11226/v23i1
Journal of Agricultural Extension

Vol. 23 (1) January, 2019

ISSN(e): 24086851; ISSN(Print); 1119944X

http://journal.aesonnigeria.org

http://www.ajol.info/index.php/iae

Email: editorinchief@aesonnigeria.org

Lack of good road network to get farmers in rural areas registered was also a constraint which needed to be tackled. Banjo, Gordon \& Riverson (2012) stressed that lack of access to good road network increases transportation cost of farm produce and such is capable of getting most farmers discouraged and this could as well affect the GES schemes' participants as transportation of these farm inputs supported by the scheme will become a problem.

\section{Table 7: Perceived constraints to effective implementation of the scheme}

\begin{tabular}{lll}
\hline Perceived constraints & Mean & $\begin{array}{l}\text { Std. } \\
\text { Deviation }\end{array}$ \\
\hline Farmers not being able to read text message on phones & $2.36^{*}$ & .646 \\
In ability of farmers to still pay for the inputs & $2.31^{*}$ & .671 \\
Untimely inputs provision & $2.20^{*}$ & .717 \\
Lack of good road to get farmers registered & $2.18^{*}$ & .682 \\
Inability to identify practicing farmers & $2.12^{*}$ & .769 \\
Inability of the participants to purchase phones & $2.08^{*}$ & .717 \\
Mixed up names of registered farmers & $2.08^{*}$ & .717 \\
Time lag between registration and input supply & 1.97 & .809 \\
In ability to reconcile the e wallet with farmers list. & 1.94 & .737 \\
In ability to access the information on the schemes' activities & 1.92 & .681 \\
Lack of sufficient farm inputs for all practicing farmers & 1.88 & .773 \\
Inadequate staff used for the schemes operations & 1.85 & .752 \\
High transportation cost of supported inputs & 1.84 & .756 \\
Lack of registrations form for all practicing farmers & 1.75 & .736 \\
Lack of adequate publicity on the schemes' activities & 1.73 & .744 \\
\hline
\end{tabular}

\section{Constraints to effective implementation of the GES scheme Activities}

The constraint variables were further subjected to factor analysis to draw out policy issues that needed to be addressed. Table 8 shows the result of the rotated matrix indicating the extracted factors on the responses of GES scheme participants. Three major factors were extracted. Factors 1, 2 and 3 were named, input related constraints, personnel related constraints and poverty related constraints.

Inputs related constraints include lack of sufficient inputs (0.75), high transportation cost of the inputs $(0.55)$, the untimely input provision to all registered farmers $(0.46)$, and lack of registration form for practicing farmers (0.69). Input availability is important if agricultural production must improve. Its availability may not be the issue rather its timeliness as such is capable of hindering the success of the GES scheme. In line with this, Amurtiya, Karniliyus, \& Chinda (2018) reported that difficulty in procuring agricultural inputs at the right time had discouraged the use of agricultural inputs by farmers in Nigeria.

Under personnel related constraints, variables that loaded include: inadequate staff used for the schemes operation (0.78), time lag between the registration period and input supply $(0.77)$, and the inability to reconcile the e-wallet with the compiled list of farmers (0.73). These constraints imply that when there are no adequate or properly trained personnel, it 
Creative Commons User License: CC BY-NC-ND

Abstracted by: EBSCOhost, Electronic Journals Service (EJS),

Google Scholar, Journal Seek, Scientific Commons,

Food and Agricultural Organization (FAO), CABI and Scopus
Journal of Agricultural Extension

Vol. 23 (1) January, 2019

ISSN(e): 24086851; ISSN(Print); 1119944X

http://journal.aesonnigeria.org

http://www.ajol.info/index.php/jae

Email: editorinchief@aesonnigeria.org

is most likely that the scheme will not succeed. In the same vein, Ojeka, Effiong, \& Eko, (2016) identified inadequate personnel to provide backup support for agricultural programmes as one of the constraints to agricultural development in Nigeria.

Variables that loaded under factors 3 (poverty related constraints) were farmers not being able to pay for the subsidized inputs (0.78), inability to purchase mobile phones (0.62) and lack of logistics to get farmers in the rural areas registered (0.67) This implies that under such constraints if nothing is done, farmers may likely be excluded from the benefits of the GES scheme programme. This is similar to Ajibo (2012) findings, which identified lack of fund as the major constraints to agricultural development among farmers in Enugu State Nigeria.

Table 8: Constraints to effective implementation of the GES scheme

\begin{tabular}{|c|c|c|c|}
\hline Variables & $\begin{array}{l}1 \\
\text { Input- } \\
\text { related } \\
\text { Constraints }\end{array}$ & $\begin{array}{l}2 \\
\text { Personnel- } \\
\text { related } \\
\text { Constrains }\end{array}$ & $\begin{array}{l}3 \\
\text { Poverty- } \\
\text { related } \\
\text { Constraints }\end{array}$ \\
\hline $\begin{array}{l}\text { Farmers not being able to pay for the subsidized } \\
\text { Inputs }\end{array}$ & 0.14 & -0.16 & 0.78 \\
\hline Inadequate publicity & 0.59 & 0.41 & 0.14 \\
\hline Lack of sufficient input for all registered farmers & 0.75 & 0.29 & 0.25 \\
\hline Farmers not being able to purchase a phone set & -0.18 & 0.38 & 0.62 \\
\hline $\begin{array}{l}\text { Lack of good road network to get farmers in rural } \\
\text { areas registered }\end{array}$ & 0.34 & 0.32 & 0.67 \\
\hline Mixed up Names of registered farmers & 0.46 & 0.47 & 0.17 \\
\hline Inadequate staff used for the schemes' operations & 0.29 & 0.78 & 0.09 \\
\hline $\begin{array}{l}\text { Time lag between registration periods and input } \\
\text { supply }\end{array}$ & 0.32 & 0.77 & 0.10 \\
\hline $\begin{array}{l}\text { Ability to reconcile the e-wallet vouchers with the } \\
\text { farmers compiled list }\end{array}$ & 0.21 & 0.73 & 0.19 \\
\hline $\begin{array}{l}\text { Farmers not being able to read text messages on } \\
\text { their phone during input redemption }\end{array}$ & 0.04 & 0.54 & 0.49 \\
\hline Lack of registration form for all farmers & 0.69 & -0.15 & -0.06 \\
\hline Untimely Input redemption & 0.46 & 0.02 & 0.15 \\
\hline High transportation cost for input supplied & 0.55 & 0.39 & -0.07 \\
\hline Ability to identify practicing farmers & 0.43 & -0.02 & 0.63 \\
\hline $\begin{array}{l}\text { Lack of access to information on the schemes } \\
\text { activities }\end{array}$ & 0.59 & 0.41 & 0.14 \\
\hline
\end{tabular}

\section{Strategies for Effective Implementation of the GES Scheme Activities}

Entries in Table 9 indicate the suggested strategies that will enhance effective implementation of GES scheme. Some of these suggested strategies include timely input provision by the scheme $(70.8 \%)$, increase in the quality of input supply to the farmers $(40.8 \%)$ and early registration of farmers as a strategy to effective implementation of the scheme $(40.8 \%)$. Timely provision of inputs is very necessary if the set goal of the scheme must be achieved. Mgbenka \& Mbah (2016) reported that if agricultural food production in Nigeria must improve, timely provision of inputs such as chemicals, fertilizers, improved seeds, farm tools and implements are to be ensured by government. Also, early 
Creative Commons User License: CC BY-NC-ND

Abstracted by: EBSCOhost, Electronic Journals Service (EJS),

Google Scholar, Journal Seek, Scientific Commons,

Food and Agricultural Organization (FAO), CABI and Scopus

http://eoi.citefactor.org/10.11226/v23i1
Journal of Agricultural Extension

Vol. 23 (1) January, 2019

ISSN(e): 24086851; ISSN(Print); 1119944X

http://journal.aesonnigeria.org

http://www.ajol.info/index.php/iae

Email: editorinchief@aesonnigeria.org

registration of participants might likely allow proper sorting of names prior to the commencement of the scheme every year and to avoid mixing up names.

Table 9: Strategies for enhancing the effective Implementation of GES activities

\begin{tabular}{lll}
\hline Perceived strategies & Frequency & Percentages \\
\hline Timely Input provision & 85 & 70.8 \\
Increase quantity of input supply & 49 & 40.8 \\
Early registration of farmers & 49 & 40.8 \\
More redemption centres to be created & 37 & 30.8 \\
Provision of mobile phones to farmers & 24 & 20.0 \\
$\begin{array}{l}\text { Involving only the extension officers } \\
\text { Provision of markets for marketing of agricultural } \\
\text { products }\end{array}$ & 23 & 19.2 \\
$\begin{array}{l}\text { Transportation cost to be reduced } \\
\text { Mobility for the scheme officers }\end{array}$ & 21 & 18.3 \\
$\begin{array}{l}\text { Publicity on the programmes activities to be } \\
\text { encouraged }\end{array}$ & 20 & 17.5 \\
\hline
\end{tabular}

Relationship Between socio-economic and institutional characteristics of rural farmers and knowledge level on GES scheme

Table 10 reveals that the socio-economic and institutional characteristics of rural farmers significantly influenced their knowledge level on GES scheme $(F=1.108 ; P \leq 0.05)$ accounting for $12.1 \%\left(R^{2}\right)$ of the variance. The study reveals that only access to agricultural related information $(t=2.340 ; P=0.05)$ had a significant influence on farmers' knowledge of the scheme. Access to information is often said to bring about awareness which is an ingredient for participation in any developmental programme. According to Edoka (2012), information is a critical resource necessary for socio-economic development as it enables people to make informed choices towards improving their agricultural production. In the same way, having access to agricultural related information improves farmers' knowledge on the activities of GES scheme which will in turn enable them make a wise decision that will improve their livelihood.

However, variables like sex of the respondents ( $t=-0872 ; p=0.386)$, age of respondents $(t$ $=0.610 ; \mathrm{p}=0.543)$, years spent in formal education $(\mathrm{t}=0.107 ; \mathrm{p}=0.915)$, religion of the respondents $(\mathrm{t}=-0844 ; \mathrm{p}=0.401)$, household size $(\mathrm{t}=0.891 ; \mathrm{p}=0.375)$ and the farming experience ( $t=0.611 ; p=0.543$ ) have no significant influence on the rural farmers' knowledge of GES scheme. Based on the result, the null hypothesis was rejected. 
Creative Commons User License: CC BY-NC-ND

Abstracted by: EBSCOhost, Electronic Journals Service (EJS),

Google Scholar, Journal Seek, Scientific Commons,

Food and Agricultural Organization (FAO), CABI and Scopus

http://eoi.citefactor.org/10.11226/v23i1
Journal of Agricultural Extension

Vol. 23 (1) January, 2019

ISSN(e): 24086851; ISSN(Print); 1119944X

http://journal.aesonnigeria.org

http://www.ajol.info/index.php/iae

Email: editorinchief@aesonnigeria.org

Table 10: Socio-economic and institutional characteristics influencing farmers GES knowledge

\begin{tabular}{|c|c|c|c|c|}
\hline \multicolumn{5}{|c|}{ Unstandardized coefficients standardized } \\
\hline \multirow[b]{2}{*}{ Variables } & \multicolumn{3}{|c|}{ Coefficient } & \multirow[b]{2}{*}{$\mathbf{T}$} \\
\hline & $\mathbf{B}$ & STD Error & Beta & \\
\hline (Constants) & 12.268 & 3.392 & & 3.617 \\
\hline Sex & -472 & .541 & -094 & -0.872 \\
\hline Age & .019 & .032 & .084 & 0.610 \\
\hline Marital status & .696 & .710 & .110 & 0.980 \\
\hline Years of formal education & .004 & .041 & .013 & 0.107 \\
\hline Religion & -374 & .443 & -091 & 0.844 \\
\hline Household Size & -080 & .090 & -118 & -0.891 \\
\hline Farming experience & -018 & .029 & .089 & 0.611 \\
\hline Access to agric. related & & & & \\
\hline Information & .504 & .643 & .246 & $2.340^{* *}$ \\
\hline Farm size & -.231 & .136 & -.172 & -1.691 \\
\hline Social/religion organization & .261 & .584 & .045 & 0.447 \\
\hline own a mobile phone & 1.089 & 2.143 & .051 & 0.508 \\
\hline farm income & 1.234E-7 & .000 & .012 & 0.121 \\
\hline
\end{tabular}

A dependent variable; knowledge of GES, R Square $=0.121$,

$R$. square adjusted $=0.012, F$ value $=1.108 ; P \leq 0.05$, significant

**The level of significance

\section{Conclusion and Recommendations}

The farmers had good knowledge of the schemes' activities which they benefited from since the inception of the programme. They were satisfied with some operational process of the scheme and also perceived some implementation processes of the scheme to be effective, however the overall mean score of 1.95, which is below the mean cut-off point of 2.0 shows perceived low effectiveness of the Scheme's activities by the participants. Also, untimely input provision, inability to still pay for the subsidized input by the farmers and not being able to purchase mobile phones hindered the Scheme's effectiveness.

The study recommends that farm inputs should be provided promptly to all participants before the commencement of the rainy season as this will enhanced its proper utilization. Again, more inputs redemption centres should be created so that farmers can have their agricultural farm inputs redeemed without having to travel a long distances. The farm inputs are to be further subsidized by the government in such a way that every participant can afford it. Lastly, provision of mobile phones to each participant should be included as one of the Schemes' package since most information on its activities especially during inputs redemption are transmitted via mobile GSM phones.

\section{References}

Adesina, A. (2012).Growth Enhancement Support Scheme, Save Agricultural Sector. Punch Newspaper. Retrieved from http://www.punch.ng.com/business lindustrygrowthenhancementsupportscheme on December 28, 2013. 
Creative Commons User License: CC BY-NC-ND

Abstracted by: EBSCOhost, Electronic Journals Service (EJS),

Google Scholar, Journal Seek, Scientific Commons,

Food and Agricultural Organization (FAO), CABI and Scopus

http://eoi.citefactor.org/10.11226/v23i1
Journal of Agricultural Extension

Vol. 23 (1) January, 2019

ISSN(e): 24086851; ISSN(Print); 1119944X

http://journal.aesonnigeria.org

http://www.ajol.info/index.php/iae

Email: editorinchief@aesonnigeria.org

Adesina, A. (2013). Nigeria, No going back on cell phones. Vanguard Newspaper. Retrieved from,http://www.vanguardngr.comon January $15^{\text {th }}, 2013$.

Aderolu, I. A., Babalola, F.D., Ugioro, O., Anagbogu, C.F., Ndagi, I., Mokwunye, F.C., Mokwunye, I. U, Idrisu, M. \& Asogwa, E.U. (2014). Production and marketing of Coffee (Coffea robusta) in Kogi State, Nigeria: Challenges and recommendation for intervention. Journal of Social Science Research, 3(2), 207-215. Retrieved from https://www.researchgate.net/publication 1282152191 Production and marketing of Coffee Coffea robusta in Kogi State Nigeria Challenges and recommendation for intervention

Ajibo, A.U. (2012). Pattern of Agricultural Diversification among Farmers in Enugu State. Undergraduate Project submitted to Department of Agricultural Extension University of Nigeria, Nsukka.

Aphunu, A. \& Nwabueze, G.O. (2012). Fish farmer's perception of climate change impact on fish production in Delta State. Journal of Agricultural Extension, Vol. 2(16), pp.113.

Banjo, G., Gordon, H \& Riverson, J. (2012). Rural transport: Improving its contribution to growth and poverty reduction in sub-saharan Africa. Sub-Saharan Africa Transport Policy Program (SSATP), 93. Retrieved from http://siteresources.worldbank.org/EXTAFRSUBSAHTRA/Resources/15139291262811936256/SSATP93-Rural-Transport.pdf

Bola, A., Aliou, D \&Omonona, T.B. (2012). Impact of Improved Agricultural Technology Adoption on Sustainable Rice Productivity and Rural Farmers' Welfare in Nigeria. Local Average Treatment Effect (Late) Technique, pp1-17.

Amurtiya, M., Karniliyus, T., A. \& Chinda, M. D. (2018). Agricultural Inputs Subsidy in Nigeria: An Overview of the Growth Enhancement Support Scheme (GESS). Acta Universitatis Agriculturae et Silviculturae Mendelianae Brunensis, 66. 781-789. 10.11118/actaun201866030781.

Edoka, M. H. (2012). Information seeking behaviour of small holder farmers in Anyigba Agricultural zone and Kogi State. A Ph.D. proposal Seminar presented at Department of Agricultural Extension, university of Nigeria, Nsukka.

Federal Ministry of Agriculture and Rural Development (FMARD), (2012). Growth Enhancement Support Scheme. Retrieved from,file://E./project/growthenhancement-support-scheme-ges.htmon 18th April, 2013.

Federal Ministry of Agriculture and Rural Development (FMARD), (2013). Review of Growth Enhancement Support (GES) scheme in 2012 and implementation strategies for2013. A Document of the National Fertilizer Development Committee.

Mgbenka, R.N \& Mbah, E.N. (2016). A review of smallholder farming in Nigeria: Need for transformation. International Journal of Extension and Rural Development Studies, $3(2)$, 43-54. Retrieved from http://www.eajournals.org/wp-content/uploads/AReview-of-Smallholder-Farming-In-Nigeria.pdf 
Creative Commons User License: CC BY-NC-ND

Abstracted by: EBSCOhost, Electronic Journals Service (EJS), Google Scholar, Journal Seek, Scientific Commons,

Food and Agricultural Organization (FAO), CABI and Scopus

http://eoi.citefactor.org/10.11226/v23i1

National Bureau of Statistics (2018). Nigerian Gross 2018). Retrieved GDP Report Q2 2018.pdf. from
Journal of Agricultural Extension

Vol. 23 (1) January, 2019

ISSN(e): 24086851; ISSN(Print); 1119944X

http://journal.aesonnigeria.org

http://www.ajol.info/index.php/jae

Email: editorinchief@aesonnigeria.org file:///C:/Users/Fabsomma/Downloads

Ogbonna, O.I. (2014). Impact of the extension services of Green River Project on fish farmers in Imo and Rivers States. M.Sc. research findings submitted to Department of Agricultural Extension, University of Nigeria, Nsukka.

Ojeka, G.O., Effiong, C.E., \& Eko, E.O. (2016). Constraints to agricultural development in Nigeria. International Journal of Development and Economic Sustainbility, 4(2), 1933.

Ojiagu, N.C., Onugu, C., \& Uchenna (2015). Effects of membership of cooperative organisations and determinants on farmer members' income in rural Anambra State, Nigeria. International Journal of Scientific \& Technology Research, 4(8), 2835. Retrieved from http://www.ijstr.org/final-print/aug2015/Effects-Of-MembershipOf-Cooperative-Organisations-And-Determinants-On-Farmer-members-Income-InRural-Anambra-State-Nigeria.pdf 